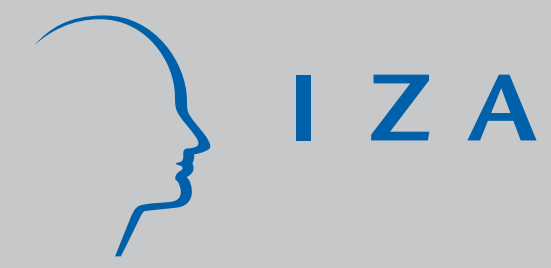

IZA DP No. 7012

Socio-Spatial Transformations, Suburbanisation, and Voting Behaviour in the Vilnius Urban Region

Rūta Ubarevičienè

Donatas Burneika

Maarten van Ham

November 2012 


\title{
Socio-Spatial Transformations, Suburbanisation, and Voting Behaviour in the Vilnius Urban Region
}

\author{
Rūta Ubarevičienè \\ Lithuanian Social Research Centre \\ and Delft University of Technology \\ Donatas Burneika \\ Lithuanian Social Research Centre \\ Maarten van Ham \\ Delft University of Technology \\ and IZA
}

Discussion Paper No. 7012

November 2012

\author{
IZA \\ P.O. Box 7240 \\ 53072 Bonn \\ Germany \\ Phone: +49-228-3894-0 \\ Fax: +49-228-3894-180 \\ E-mail: iza@iza.org
}

\begin{abstract}
Any opinions expressed here are those of the author(s) and not those of IZA. Research published in this series may include views on policy, but the institute itself takes no institutional policy positions. The IZA research network is committed to the IZA Guiding Principles of Research Integrity.

The Institute for the Study of Labor (IZA) in Bonn is a local and virtual international research center and a place of communication between science, politics and business. IZA is an independent nonprofit organization supported by Deutsche Post Foundation. The center is associated with the University of Bonn and offers a stimulating research environment through its international network, workshops and conferences, data service, project support, research visits and doctoral program. IZA engages in (i) original and internationally competitive research in all fields of labor economics, (ii) development of policy concepts, and (iii) dissemination of research results and concepts to the interested public.
\end{abstract}

IZA Discussion Papers often represent preliminary work and are circulated to encourage discussion. Citation of such a paper should account for its provisional character. A revised version may be available directly from the author. 
IZA Discussion Paper No. 7012

November 2012

\section{ABSTRACT}

\section{Socio-Spatial Transformations, Suburbanisation, and Voting Behaviour in the Vilnius Urban Region}

This paper analyses the interrelationship between the process of suburbanization and a changing political and ethnic landscape in the Vilnius urban region. The region surrounding Vilnius city is dominated by Polish identity residents while those who suburbanise into the region are mainly ethnic Lithuanians. This may lead to potential tension and conflicts in the region which may find its expression in the voting behaviour of residents of the region. Using data from the 1997 and 2011 municipal elections we found that the share of votes for the Polish party in the region decreases over time, while the absolute number of votes for this party increases. At the same time we find increasing voting activity in the suburban ring. The changing electoral behaviour can be regarded as an indicator of a growing ethnic identity. The voting results also identify the zones of the most intense changes in the electoral behavior and thus indicate areas of potential social tensions between two ethnic groups.

JEL Classification: D72, J15, R11, R14, R23

Keywords: $\quad$ suburbanisation, ethnicity, conflict, voting behaviour, electoral data, Lithuania

Corresponding author:

Rūta Ubarevičienè

OTB Research Institute for the Built Environment

Delft University of Technology

PO Box 5030

2600 GA Delft

The Netherlands

E-mail: ruta.ubareviciene@gmail.com 


\section{INTRODUCTION}

Political reforms in the early Nineteen Nineties in the former socialist countries of Central and Eastern Europe led to major economic and social changes. These transformations have a clear expression in the spatial development of the major cities of post-communist Europe (Hamilton et al. 2005; Timar \& Varadi 2001). Suppressed urbanization and rural retention during the Soviet period resulted in explosive changes in land use patterns after the introduction of the market economy in these states (Bertaud \& Renaud 1997; Boren \& Gentile 2007). One of the most significant features of this spatial process was urban expansion through the process of suburbanization (Timar \& Varadi 2001; Nuissl \& Rink 2005; Ouředníček 2007; Tammaru et al. 2009; Tammaru et al., 2011; Kok \& Kovács 1999; Leetmaa \& Tammaru 2007; Novak \& Sýkora 2007). Like many other formerly centrally planned cities in Europe, also Vilnius - the capital of Lithuania - is undergoing rapid suburbanization, a process which started right after 1990 (see Ubarevičienè et al. 2011; Burneika \& Ubarevičienè 2011; Bardauskiené \& Pakalnis 2011; Brade et al. 2009). The processes of urban sprawl and outward mobility in Vilnius are quite similar to what can be observed in other post-Soviet countries (Boren \& Gentile 2007; Novak \& Sýkora 2007; Krišjāne \& Bērziņš 2009).

What makes the case of Vilnius specific is the ethnic landscape of the central city and the region surrounding the city. Due to historical reasons, the region surrounding Vilnius is dominated by ethnic minority groups (with the prevalence of Poles) and it is regarded as the most multinational region of Lithuania (Stanaitis \& Česnavičius 2010). Ethnic minorities comprise $36,8 \%$ of the Vilnius city population and approximately $65 \%$ of its' recent suburbanization zone (Statistics Lithuania, 2012). In addition, the ratio of different national groups differs considerably between the central city and the region surrounding it. Although Poles comprise around half of the population in the zone of suburbanization, they form a clear majority in the areas that are still unaffected by suburbanization (more than $90 \%$ in some LAU 2 regions) and less than one fifth in the central city. The proportion of ethnic minorities is relatively high throughout the region, but the contrast in their quantities and national composition is evident. What makes Vilnius unusual in an international context is that the spatial pattern of ethnic composition in Vilnius is the opposite of what is found in many European cities where the central city has a high share of ethnic minorities and where the commuter ring around the city is dominated by the native population.

The recent process of suburbanization, which takes place in the territories predominated by ethnic minorities, might have negative social consequences. As has been observed in many other countries (Tammaru el al. 2011; Bonvalet et al. 1995; Clark 2006; Simpson \& Finney 2009; Hiebert 2000) the ethnic majority population is overrepresented among those who suburbanise. In the case of Vilnius Lithuanians suburbanise to the surrounding city region where Polish identity residents are the largest group. The outward expansion of Vilnius city results in a confrontation of groups in the suburbs, with partly different needs, priorities, worldviews, quality of life standards, and value systems (Burneika \& Ubarevičienè 2011). Ethnic, social, political and economic contrasts are evident between the old residents of the city region and the newcomers. That this can lead to potential conflicts is illustrated by the increasing media attention for the growing identity of the Polish minority in the Vilnius region and possible links with the ethnic dimensions of the ongoing suburbanization process.

The aim of this paper is to explore the relationship between suburbanization and changing electoral behaviour of national minorities. As George, Moser and Papic argue (George et al. 2010), a strong salience of group identity can be revealed through political action. Therefore, in this study we will explore the use of electoral results to gain insight into 
changing identities. The vast majority of ethnic minorities in the region surrounding Vilnius city support Polish political parties that appeal almost exclusively to their interests. We expect that the suburbanization process and voter migration might have consequences for electoral results in the surrounding city region. We hypothesise that the Polish identity voters will show an increase in voting activity and will more often vote for the Polish parties in order to strengthen their political influence in a time where 'others' enter the region. As a result we expect to find increasing voting rates and increasing votes for the Polish parties in the suburbanisation ring around Vilnius.

This study uses electoral data of 1997 and 2011 municipality elections. We will discuss the opportunities and problems associated with the use of electoral data in a study of growing national identities of ethnic minorities. The Lithuanian Census of 1989, 2001 and 2011 provide us with information about population change and ethnic composition. The smallest possible statistical units - voting districts and seniunija (LAU 2 or previous NUTS 5 level) are used to give precise territorial data. Cartographical analysis is used to investigate the correlations between socio-spatial transformations and voting behaviour in the Vilnius urban region.

\section{CHANGING ETHNIC COMPOSITION OVER TIME}

Although there is a rich literature describing the population and migration history of the Vilnius region, there is little agreement on the 'correct' reading of history. The region has been part of several nation states over the course of time and because of the political, cultural and ethnic backgrounds of authors and researchers, a variety of interpretations of the same historical events is more a rule than an exception (see Gaučas 1997; Valionis et al. 1999; Snyder 1995; Zubek 1993). Up to the $19^{\text {th }}$ century there are no reliable population statistics (Gaučas 1997), and even more recent census data and the interpretation of the census are not undisputed. Each government collected data for their own political and military purposes and used techniques suiting their own needs. As a result it is difficult to compare census data over time. Also the administrative boundaries that data is collected for have changed over time. The above have led to a situation where the literature often offers contradictory information. In this paper we give a reading of history by marking the main historical events, which influenced the present ethnic landscape of the Vilnius region, while trying to avoid disputed interpretations of the events and the factors that led to them.

The contemporary presence of a Polish identity population in the Vilnius region is strongly rooted in history. The Grand Duchy of Lithuania, which was the largest state in Europe in the $15^{\text {th }}$ century, with borders stretching from the Baltic to the Black Sea, became a constituent part of the Polish-Lithuanian Commonwealth, established in 1569. The new Commonwealth led to the spread of Polish language and identity, because Polish was adopted by the governors and nobility as the main language in the union (Hogan-Brun \& Ramoniene 2003; Valionis et al. 1999; Gaučas 1997). Vilnius city itself became a core of the spread of Polish language into the surrounding region. In the late $18^{\text {th }}$ century the whole of contemporary Lithuania became part of the Russian empire, but Polish language and identity remained important in the region (Hogan-Brun \& Ramoniene 2003). At the same time, the influence of the Russian culture and language spread. It was also a period of intense immigration from nearby Belarus with effects on especially the eastern part of the Vilnius region. Simultaneously, a regional dialect began to spread in the region as a consequence of the competing Russian, Belarusian, Polish and Lithuanian languages. This dialect was officially considered to be a Russian language dialect by the Czarist government, while Polish 
protagonists declared that it was a dialect of Polish language (Gaučas, 1997). Although the Lithuanian population had been declining (at the end of $19^{\text {th }}$ century Lithuanians made up only $2 \%$ of the population of Vilnius city and $35 \%$ of the surrounding region, Gaučas, 1997), throughout this whole Russian period, a Lithuanian national movement was active in the region. There were attempts to restore the public rights of the Lithuanian language and there were illegal Lithuanian language schools. The complex history of the Vilnius region and its location in the encounter zone between the Baltic's and Slavic's ethnical lands led to the formation of an uncertain national (regional) identity, a situation which, to some extent, persists until the present day.

Historical events in the $20^{\text {th }}$ century had a decisive impact on the present ethnic composition of the city and its surrounding region. Throughout this century, the administrative and territorial borders of Vilnius city and its region shifted frequently and the territory belonged to Russia, Germany, Poland, the Soviet Union and Lithuania at various points in time. All these changes had significant impacts on the ethnic composition of the population (Stanaitis 2003; Stanaitis \& Česnavičius 2010; Hogan-Brun \& Ramonienė 2003). Each new ruling government imposed its own ideologies and culture, which was expressed mostly through regulations in education, religion and press (Gaučas 1997; Paltanavičiūte 2004). The present situation where the Vilnius region distinguishes itself from the rest of Lithuania by the high share of Polish identity residents finds its origins in the period of Polish governance between 1920-1939 (according to Paltanavičiūte 2004, nowadays more than 80\% of Poles in Lithuania are concentrated on $8 \%$ of the land mass, which is the Vilnius region). This period showed a strong growth of the Polish population as well as the strengthening Polish identity of local residents throughout Vilnius region, which could have been characterised as an area of uncertain national identity until then. Meanwhile, the rest of Lithuania was an independent state between 1918 and 1940, which strengthened the Lithuanian identity across this part of the country.

The Second World War was a new period of population change for Vilnius city. The population halved and the ethnic composition changed. Two events were responsible for this. First, the Holocaust reduced the Jewish population in the city from 57 to only 2 thousand while Jews comprised $30-50 \%$ of the total population at various points in time since the $15^{\text {th }}$ century (Vaitiekūnas 2006; Mendelsohn 1983). Second, the war marked the end of the Polish governance and the beginning of the Soviet period. This shift in power was accompanied by Polish repatriation - 100-150 thousand Poles emigrated from the Vilnius region during the 1944-1948 period (Daukšas 2008). The majority of the emigrants originated from the city of Vilnius, while the repatriation from the surrounding region proportionally was much smaller (Stravinskienè 2004). At the same time, mass industrialisation, which began soon after the start of the Soviet occupation, accelerated the growth of Vilnius city. The population of the city increased 3.4 times between 1950-1989 (Stanaitis \& Česnavičius 2010; see also Enyedi 1996; Krišjāne \& Bērziņš 2009; Sýkora \& Ouředníček 2007 on industrialization in Soviet cities). Vilnius city was filled up by immigrants from other parts of Lithuania and more remote areas of the Soviet Union. According to Stanaitis and Česnavičius (2010), representatives of three nationalities dominated Vilnius city throughout the Soviet years: Lithuanians, Russians and Poles, with a steadily increasing Lithuanian population. They argue, that this increase "is associated with Vilnius development as a capital and strengthening of national identity" (Stanaitis \& Česnavičius 2010, p. 36). The impact of the Second World War on the region surrounding Vilnius city was limited, mainly because this area was not of any strategic importance. Also the effects of the Soviet regime on the ethnic structure of the region were relatively weak: the population remained to consist of mainly Polish residents, although there was an increase in the number of Belarusians. 
The ethnic composition of Vilnius city underwent one more period of change in recent history: in the period since the restoration of Lithuanian independency in $1990^{1}$. The period of population growth that lasted throughout the Soviet years ended (Stanaitis \& Česnavičius 2010; Stanaitis 2003), and as in many other post-Soviet countries, part of the Russianspeaking residents emigrated (see Tammaru \& Kulu 2003; Commercio 2004). The proportion of Lithuanian people in Vilnius has grown by 12,7\% since 1989 and according to the last census (Statistics Lithuania, 2012) is now 63,2\%. It should be noted that no nationality has comprised such a large proportion of the total population at least since the establishment of Polish-Lithuanian Commonwealth in 1569. Contrary to the situation in the city, the ethnic structure of the surrounding rural region has changed very little since the beginning of the $20^{\text {th }}$ century. Figure 1, which is based on the data of 2001 census (Statistics Lithuania, 2002), clearly illustrates this cleavage - Lithuanians dominate the city of Vilnius and Polish identity residents dominate the surrounding region. Ethnic minorities comprise approximately $65 \%$ in the area where recent suburbanization of Vilnius takes place, with the largest ethnic groups being Poles (49\%), Lithuanians (37\%), Russians (8\%), and Byelorussians (3\%). Meanwhile, the most numerous ethnic group in Vilnius is Lithuanians $(63,2 \%)$ followed by Poles $(16,5 \%)$, Russians (12\%) and Byelorussians (3,5\%).

In the last 10-15 years, the importance of ethnic identity is increasing in the Vilnius region, especially among those with Polish identity. Right after the restoration of Lithuanian independency, the Polish community in Lithuania did not have strong relations with Poland and there were no local ethnic organizations representing their interests. Only the resistance identity (see Castells 2004), which was based on a historical and geographical basis, distinguished this region from the remaining part of Lithuania. For example, the residents of the region surrounding Vilnius have shown the lowest support for a Lithuanian independence in the 1991 referendum (Snyder 1995). Similar results in the referendum for Lithuanian membership of the EU in 2003 also confirms the 'resistant' origin of this population (Central Electoral Commission, 2003). Over time, resistance identity was supplemented by the legitimizing identity (see Castells 2004). The creation and active propagation of a Polish political party (its official name is "Electoral Action of Poles in Lithuania") had an important role in the formation of a strong ethnic identity among Poles. This political party was established in 1994, but only a few years later it started to act as a major force in unifying the ethnic minorities in the region. Petrulis (2009) has argued that the Vilnius region has now become an independent social-political entity in Lithuania. The ethnic identity of Poles is also supported through the educational system and local media. Although the number of schools has halved throughout Lithuania during the last two decades, the number of schools in the Vilnius region has been increasing since 1989. There were 44 Polish schools of general education in 1989 (Savukynas 2000) and 56 schools in 2011. The number of pupils decreased by $40 \%$ in Polish schools during the last decade (Statistics Lithuania, 2011). These new schools were established by municipalities which are governed mostly by Poles.

\section{URBAN SPRAWL}

All the major cities of Central and Eastern Europe (CEE) have followed a similar path of rapid and profound changes in their spatial organization since the demise of the Soviet Union (Novak \& Sýkora 2007; Sýkora \& Ouředníček 2007; Nuissl \& Rink 2005; Sailer-Fliege

\footnotetext{
${ }^{1}$ During the political reforms of the 1989-1990s the citizenship act was possessed in Lithuania. According to this act all permanent residents of the territory of Lithuania, regardless of their origin, were able to acquire Lithuanian citizenship. It was accepted by $90 \%$ of the non-Lithuanian residents.
} 
1999). These changes were determined by the transition from centrally planned economies, to market led economies (Gentile et al. 2012; Stanilov 2007; Kostinskiy 2001). The urban structure of post-Soviet cities is an integral part of the legacy from the Soviet planning system. Although the process of territorial transformations is common to all CEE states, the complex interaction of inherited cultural, political, economic and institutional settings (Boren \& Gentile 2007) from the Soviet times, new state institutional parameters (Sailer-Fliege 1999) and different means and pace of acquiring property and capital (Timar \& Varadi 2001) in the market economy, led to a unique development of spatial organization of different cities. The most prominent spatial changes in Vilnius city, as in many other cities, are related to the urban expansion to the surrounding rural region.



Figure 1. Ethnic landscape and urban sprawl of the Vilnius region.

Like in many other CEE cities, during the Soviet times, the hinterland of Vilnius was devoted exclusively to agricultural and associated industrial production (see, for example, Leetmaa \& Tammaru 2007; Sýkora \& Ouředníček 2007; Tammaru et al. 2009). The absence of a land market and private property contributed to the situation that until the 1990s suburbs did not exist (Bertaud \& Renaud 1997; Krišjāne \& Bērziņš 2009; Sýkora \& Ćermák 1998). Compact high-density residential housing estates at the edges of cities and large industrial areas within their limits were among the most important features of urban development in the Soviet times. It should be noted that at the same time there were proposals to reduce the dominance of large cities by the development of new regional centres and promoting decentralization of industry (Tammaru 2001; Enyedi 1996). In Lithuania this meant that part of the potential growth of 
Vilnius was distributed to other regions of Lithuania. However, this policy did not work out as planned and Vilnius has grown faster than was expected: the administrative territory of Vilnius city has doubled during the Soviet era. While growing, it covered rural areas populated by Poles.

After the collapse of the Soviet Union, the introduction of a free market economy and privatization liberated previously constrained Vilnius growth potential and allowed the city space to grow very fast. This led to the excessive and uncontrolled urban sprawl to the surrounding rural region. Both formal and informal growth of the city is shown in Figure 1. The administrative territory of Vilnius city municipality has grown by 30\% from 1990 until 2001. However, the process of urban sprawl was faster than the extension of the formal city limits. According to the last census (Statistics Lithuania, 2012), the population of Vilnius city decreased by 40,000 (7\%) and increased by approximately 15,000 (14\%) in the city suburban zone since the restoration of Lithuanian independency. As a result, the Vilnius city region (or in other words - metropolitan area $)^{2}$ - a phenomenon which did not exist in Soviet times developed over the last two decades. The limits and structure of this city region as well as the spatial pervasion of suburbanization process were investigated in recent research on the spatial development of Vilnius (Ubarevičienė et al. 2011; Burneika \& Ubarevičienė 2011). The largest area, as shown in Figure 1 - Vilnius city region - , is the zone of everyday commuting flows. The middle area is the zone of detached suburbanization, which experiences rural-urban transformations, but rural landscape clearly prevails there. The smallest zone surrounding the city is one of intense suburbanization, which presents an area, where urban landscape and perceptions start to dominate, but rural ones are still visible. The fragments of rural landscape still exist inside the city limits, thus the process of suburbanization also includes the peripheral parts of the city. All the areas affected by the process of suburbanization experience the change of ethnic composition. They also are sites of increasing interaction between the native Polish identity residents and the Lithuanian suburbanites.

The current situation in the city of Vilnius and the surrounding region is characterised by an increasing proportion of Lithuanians in the city of Vilnius, and a recent process of rapid urban sprawl. As it is the case in many other countries, the native population of Lithuania is overrepresented among those suburbanising from the central city to the surrounding area (see Tammaru el al. 2011; Bonvalet et al. 1995; Clark 2006; Simpson \& Finney 2009; Hiebert 2000). Although there were no serious conflicts between Lithuanians and Poles in the Vilnius region, the recent process of rapid urban sprawl may stimulate the social tensions. These groups not only have linguistic differences, but also vary in their social, cultural and economic structure (Snyder 1995). The suburban ring of Vilnius might therefore become a possible stage of social and ethnic tensions between the Polish identity residents and the incoming Lithuanians. These tensions may be revealed in the voting behaviour of both groups as it can be expected that both groups feel the urge to be represented politically. Especially for Poles it is important to sustain their national identity and local political power as a tool for defending it.

In the remaining part of this paper we explore the opportunities offered, and the problems associated with the use of electoral data to investigate the effects of urban sprawl. The availability of statistical data on LAU 2 and lower levels in Lithuania is limited and the use of voting results might be a novel approach to investigate issues associated with the ethnic dimension. The unique ethnic landscape, with sharp spatial boundaries and distinct political

\footnotetext{
${ }^{2}$ Functionally and spatially integrated geographical system, functioning as an economic and social entity, where the core city is one of the main factors of the development of the area and vice versa (Ubarevičiene et al. 2011; Harrison 2010; Jonas \& Ward 2007; Krišjāne \& Bērziņš 2009; Sýkora \& Ouředníček 2007)
} 
preferences in the inner city and the surrounding region make such an approach worthwhile. We predict that the process of rapid suburbanization leads to changing electoral behaviour of the ethnic minorities in the region surrounding Vilnius. We expect that the newcomers of Lithuanian origin encourage ethnic minorities to participate in the elecions more actively and become more supportive of Polish political parties. We hypothesise that the most significant changes in the local electoral behaviour exist in the areas where the process of suburbanization is the most intense.

\section{DATA AND METHODS}

To test our hypotheses, we employ the voting results of the 1997 and 2011 municipality elections. The electoral data are the most reliable source for a detailed spatial analysis of the studied phenomenon - spatial correlations between changing strength of ethnic identity of national minorities and process of Vilnius urban sprawl. First of all, as Wolfinger (1965) argues, ethnicity plays a major role in politics and it is often an important independent variable in voting behaviour. Also, the statistics of election results are provided for voting districts, which are few times smaller than the lowest territorial level of the census in Lithuania. In addition, the frequency of elections is suitable for continuous monitoring since data is constantly updated (the different types of elections are held almost every year, sometimes several times a year).

As mentioned above, we use the lowest possible observation level - voting district. According to the Lithuanian law, each of these units cannot contain more than 5,000 voters. Officially there are no marked boundaries of these units ${ }^{3}$. Moreover, the number of voting districts as well as their size has changed over the sample period, which makes comparison over time a challenge. We have mapped the limits of voting districts to get a clear representation of their territorial dimensions. These boundaries were approximated and homogenized into a unified grid, which was used to compare data of election results in different years. We took the most recent voting districts as a basis. Territorial distribution of voting results in previous years was revised according to these established limits. Since, the process of urban sprawl is central in this study, in the empirical part of the paper we are limiting our explorations of voting data to the region which is under the direct influence of Vilnius city. This research area covers about $8000 \mathrm{~km}^{2}$ and contains approximately 750,000 inhabitants. We have analysed 316 voting districts in total. The average district has approximately 2000 voters and covers $26 \mathrm{~km}^{2}$.

Our exploratory analysis draws on a fairly straightforward method. First, we have created a database, where voting results were collected. Then cartographical tools have been used to present these results. The relationship between changing electoral behaviour of ethnic minorities and suburbanization process are being examined in this paper.

\section{EXPLORATION OF VOTING DATA}

\section{Ethnicity and voting behaviour}

The population of Vilnius city and the region surrounding the city differ not only in ethnic, cultural and economic aspects, but also in their political attitudes and, as a result, voting behaviour. In areas of the Vilnius region where Polish identity residents are in the majority,

\footnotetext{
Each district serves its own addresses, streets, individual neighborhoods, houses or villages.
} 
the Polish political party - "Electoral Action of Poles in Lithuania" (EAPL) - has leading positions. Since its foundation in 1994, EAPL has a majority in the councils of municipalities in the region surrounding the city of Vilnius. Although there have not been any detailed studies investigating the relationship between the ethnic composition of the population and the political preferences expressed through voting behaviour, the high spatial correlation between the ethnic landscape and election results suggests that a decisive factor in determining voting preferences of a large proportion of the population is their Polish identity. Research from other countries confirms the presence of ethnic voting (Wolfinger 1965; Chernyha \& Burg 2012; Crowley 2001; Medrano 1994; see Walks 2006 on the influence of different factors on political preferences).

Figure 2 clearly illustrates the differences in voting behaviour between Vilnius city and the surrounding region in both the 1997 and 2011 municipal elections. The region surrounding the city is characterised by a great support for the Polish political party, with the EAPL yielding as much as $95 \%$ of the votes in a large number of districts. The city of Vilnius itself is characterised by much lower levels of votes for the EAPL with less than $15 \%$ of the votes going to this party for most of the city.

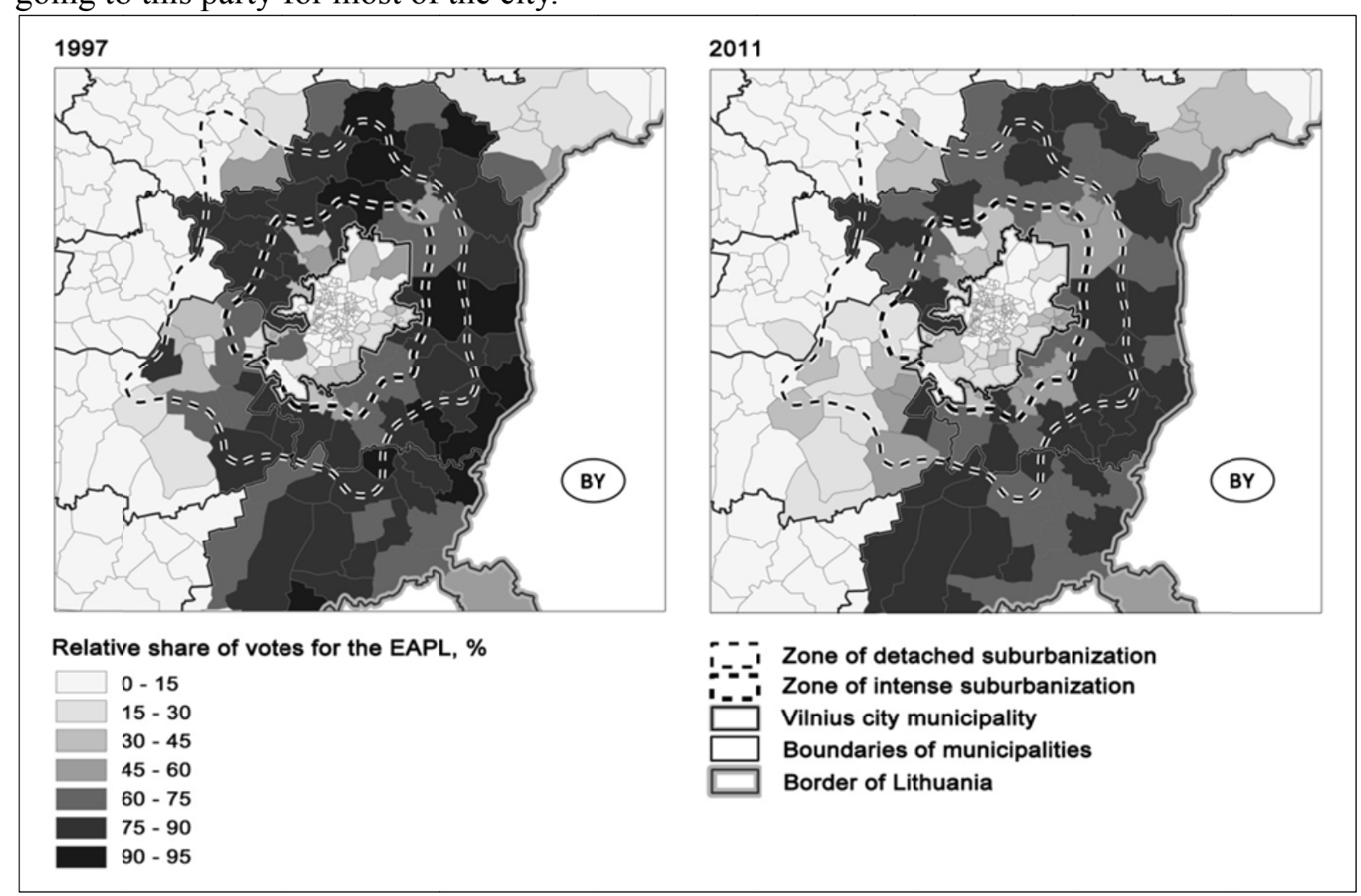

Figure 2. Relative share of votes for the EAPL in 1997 and 2011 municipality elections.

Figure 3 shows the spatial changes of the proportion of voters supporting the EAPL between 1997 and 2011. The relative popularity of the party increased in some and decreased in other parts of analysed area, but the overall picture shows a decrease in relative support for the EAPL. This is most likely related to the process of rapid suburbanisation that resulted in flows of population from the central city to the surrounding Vilnius region. Newcomers, most of whom are ethnic Lithuanians, have different political preferences than the original population, and the increase of their population in this region predominated by Polish identity residents redistributed the rankings of the competing political parties. It is known that migration flows can have major effects on electoral change even in places without such ethnic imbalances (see 
Robinson \& Noriega 2010 on the theory of voter migration; and see Halla et al., 2010 on causal effects of immigration on election outcomes).

Our results show that the relative decrease in the support for the EAPL is corresponding with the zones of detached and intense suburbanization as denoted by the dotted lines in Figure 3. The share of votes for the EALP remains stable in the areas of less intense suburbanization. The increase of the relative support appears in the zones, which are not affected by suburbanization, namely central and most peripheral parts of the region. It must be noted that the Polish political party still receives more than $50 \%$ of the votes in the majority of voting districts in the surrounding Vilnius region, especially in its periphery.

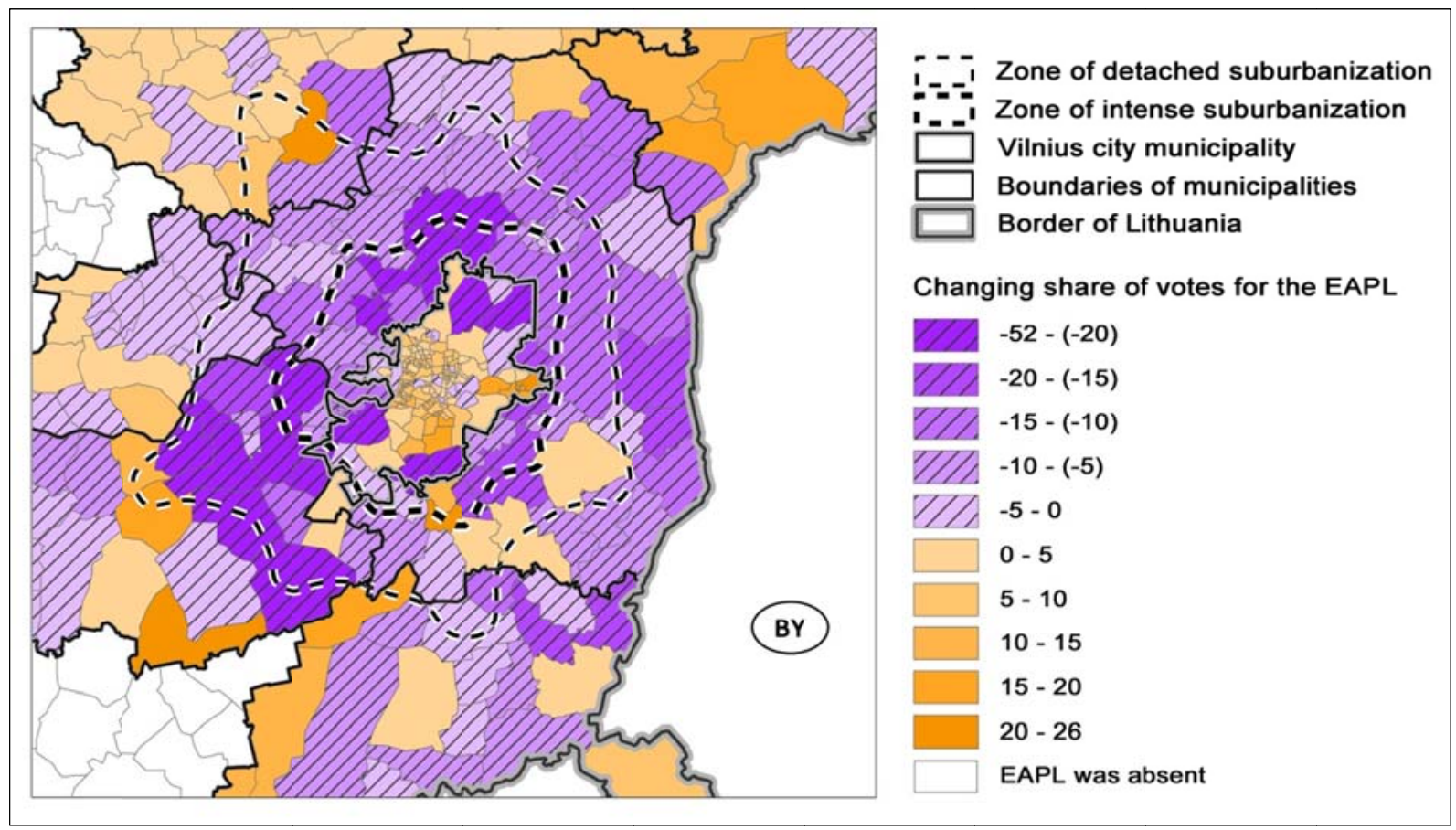

Figure 3. Changing share of votes for the EAPL in 1997-2011 municipality elections.

The changing support for the EAPL can theoretically be caused by changes in the population composition, or by changing political behaviour sitting residents. The increase of the share of votes for the EALP in the city of Vilnius could be explained by the outflow of voters for other parties, but there are no data confirming this hypothesis. It is also possible that the Polish population became more active in the city. However, the main reason for this increase is probably rooted in a different cause. Just before the 2011 elections, the EAPL formed an electoral coalition with the Russian ethnic party -"Russian Alliance" (RA) in the municipalities of the Vilnius region. The EAPL was clearly dominant in this coalition ${ }^{4}$. Although the RA has never been popular in the surrounding region and did not participate in recent municipal elections in the region (except in one unsuccessful case in one of the municipalities), it had a more significant role in Vilnius city municipality (the RA received $4,4 \%$ of votes in the 2007 Vilnius municipal elections). The collaboration between the EAPL and the RA enabled the EAPL to strengthen its position in the city. Nonetheless the support for the EAPL, even in the coalition with RA, remained relatively low in the city compared with the support in the rest of the region. The substantial increase of the share of votes for the EALP in the more remote parts of the larger region cannot be explained only by the formation

\footnotetext{
${ }^{4}$ We will use the term EAPL in the remaining parts of the paper when talking about the coalition of the EAPL and RA in 2011.
} 
of the coalition, because of the small proportion of the Russian population here. This increase is most likely the result from increased voter activity of the Polish population in this area, possible due to an increased awareness of an expanding city of Vilnius, changing the lives of those living around the city.

\section{Absolute number of votes for the EAPL}

Although the relative share of votes for the EAPL has dropped in the surrounding Vilnius region (see Figure 3), Figure 4 shows that the absolute number of votes for this party actually increased during the same time. This strengthens the idea that the Polish population becomes more active as a result of the process of suburbanisation. We found that in the surrounding city region, the total number of votes for the Polish party has increased by $6,225(16 \%)$, while the relative share of votes for this party decreased by $2,6 \%$. In the zone of most intense suburbanization (including the peripheral parts of the city municipality) there was an increase of approximately $4,100(28 \%)$ votes for the EAPL, and a $13 \%$ decrease in share of votes. It is not likely that such a growth of the number of votes originated from a growth of the Polish population. Censuses show that their population is decreasing in the region (Census 2011, Pileckas 2003). Thus the most likely reason for this increase in Polish votes is an increased voter activity among Polish identity residents. We also know that the total number of voters in the region has risen by approximately 18,000. These are mainly newcomers of Lithuanian origin, who have different political preferences than the original population in the region. We may make an assumption that such a situation encourages the Polish identity residents to participate in the elections more actively and become more supportive for their ethnic party in order to maintain its political leadership in the region.



Figure 4. Change in absolute number of votes for the EAPL in 1997-2011 municipality elections.

\section{Spatial variation in voter activity}

Numerous studies have noted that ethnic minorities are less likely to vote than the majority population (Bullock \& Hood 2006; van Heelsum 2005; Fennema \& Tillie 2001; Crowley 
2001; Torgeby 1999). Such a situation was common in the Vilnius region right after the 1990s. However, if political groups representing the interests of ethnic minorities exist, it might mobilize them to express their political views more actively in order to gain a greater socio-political influence (George el al. 2010; Wolfinger 1965; Crowley 2001; Chandra \& Wilkinson 2008). The region surrounding Vilnius city is a typical example of such phenomenon. We assume that an active political participation of Polish identity residents in the municipal elections expresses their self-identification with the region and emphasizes their ethnic identity.

The region surrounding Vilnius stands out by an exceptionally high voter activity in the municipal elections and by a relatively low activity in the central government elections since the restoration of Lithuanian independency (Central Electoral Commission, 2012). This is the opposite to what can be observed in the rest of Lithuania, where voter activity in the elections of central government - Parliamentary as well as Presidential - is highest. These differences suggest that the regional (Polish) identity is stronger than the national Lithuanian identity among the residents of the region surrounding Vilnius (see also Chernyha \& Burg 2012). One could make the assumption that the majority of the Polish identity residents in the region have a weak Lithuanian national identity and therefore little motivation to participate in the elections of central government. Most do not expect that their representatives could be elected in national elections, or make any impact on national policy. Furthermore, the mass media in Lithuania as well as the EAPL itself often depicts the Polish population as Poles in Lithuania, not Lithuanian Poles (it is even stated in the name of their party). Such an approach alienates this group from the rest of Lithuanian society. At the same time, more is at stake at the municipal elections, because people can vote for their 'own government' and emphasize their identity. Our findings suggest that an increase in voting activity in the region occurred due to a more active participation of Polish identity residents. Those places where there is an increase in voter activity in the region could be areas of rising social tensions between the local residents and newcomers.

Figure 5 shows voter activity in the 1997 and 2011 municipal elections in the city of Vilnius and the surrounding region. It can be seen that voter activity is lowest in the city and highest in the region. It can also be seen that voter activity increased significantly between 1997 and 2011, especially in districts dominated by Polish identity residents to the south and east of the city. The most 'active' areas in 2011 correspond with the areas of the highest proportion of Polish population (compare Figures 5 and 1). In 2011, in many of the voting districts, voter activity exceeded $60 \%$, while both in Vilnius city and the rest of Lithuania the average activity in the municipal elections was only $44 \%$. 


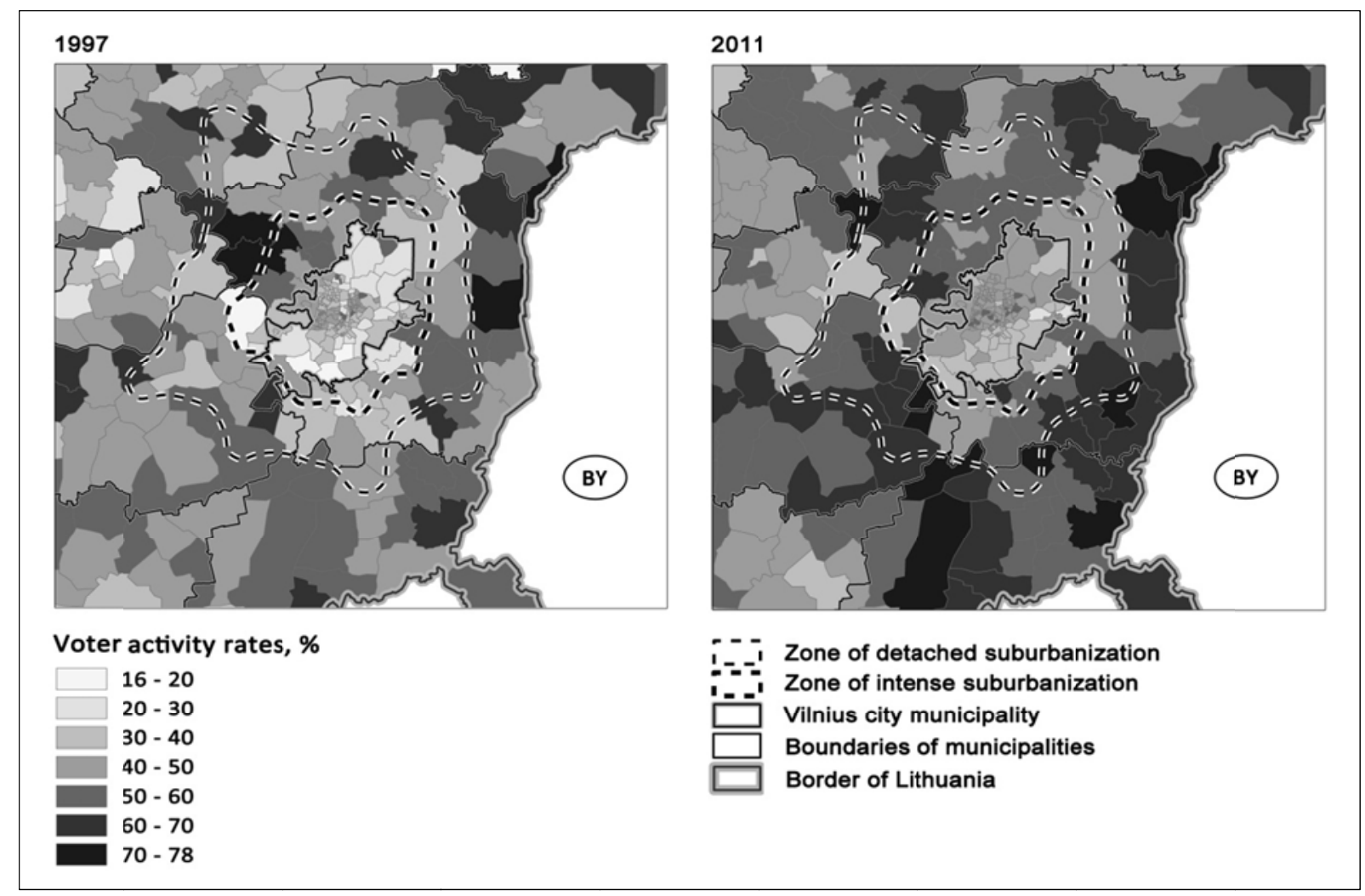

Figure 5. Voter activity rates in 1997 and 2011 municipality elections.

Figure 6 clearly shows the increase in voter activity in the zone of suburbanization, while the central part of the city remains more stable. Figure 6 also shows that areas with substantially increased voter activity coincide with areas where the relative support for the EALP decreases, especially to the south west and south east of the city (compare Figures 3 and 5). These are the areas of potential political and ethnic tensions.

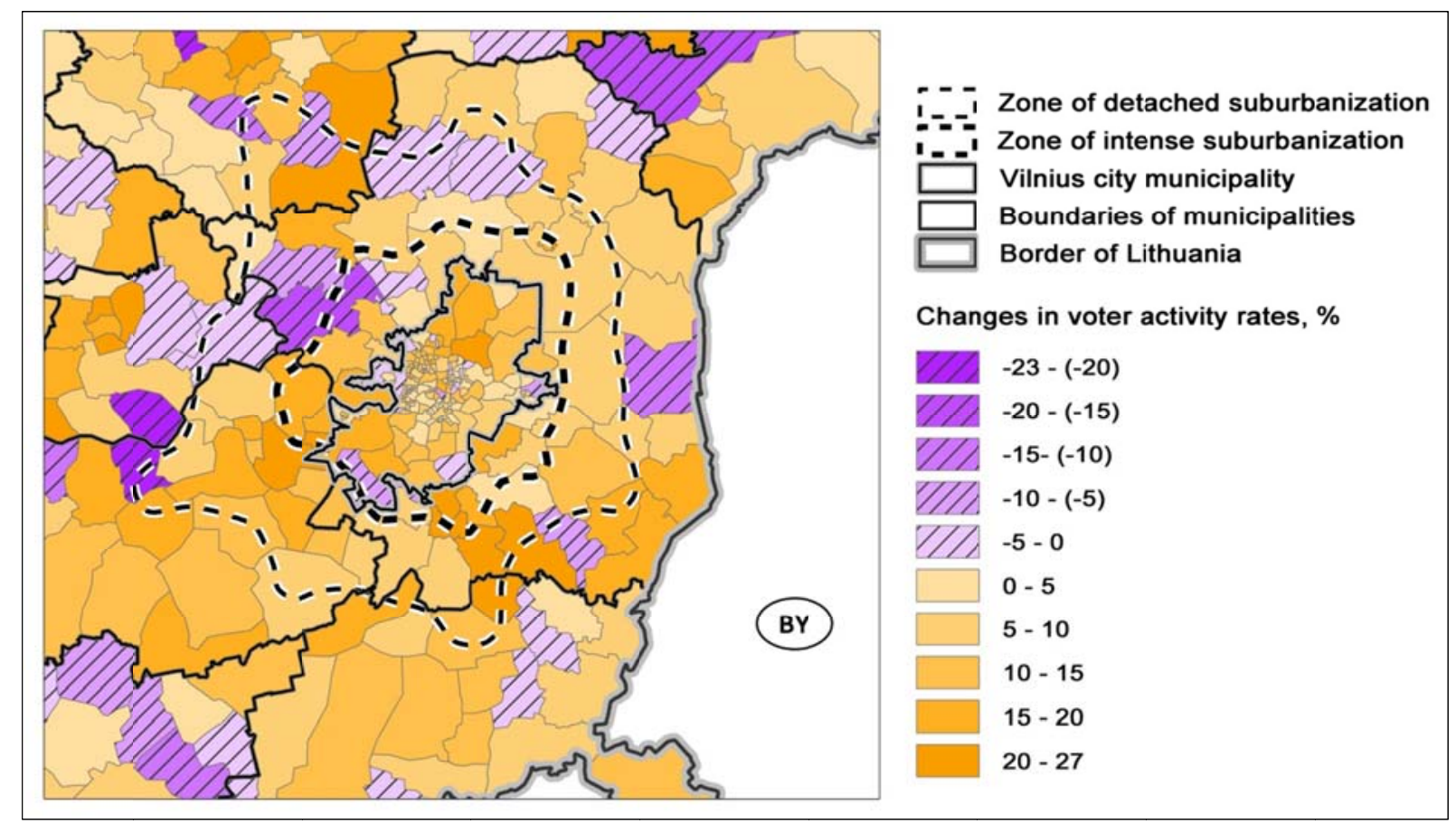

Figure 6. Changes in voter activity rates in 1997-2011 municipality elections. 


\section{CONCLUSIONS}

As noted in the introduction, Vilnius is unusual in that the spatial pattern of ethnic composition in the city region is the opposite of what is found in many European cities. The inflow of ethnic Lithuanians from the city into the suburbanisation zone surrounding the central city, which is dominated by Polish identity residents, might lead to socio-ethnic tensions. This is the first study to investigate the effects of suburbanisation on this potential for conflict by using electoral data. The idea was that voting behaviour, and especially voting for the Polish party (EAPL), and voter activity will be influenced by the suburbanisation process. The analyses of voting behaviour could indicate areas of potential social and ethnic tensions between the mostly rural Polish population and the incoming urban Lithuanian population.

Our results showed that due to the unique ethnic landscape, there are clear spatial patterns in voting behaviour. The region surrounding the city of Vilnius is dominated by those who vote for the EAPL. Analysis of the changes in the share of votes for the EAPL between 1997 and 2011 shows a decrease in the share of votes in the suburbanization ring around Vilnius. At the same time we observed an increase in the absolute number of votes for the EAPL in the surrounding region, and we found a stark increase in voter activity in the region, especially in the parts with the higher proportion of Polish population. These findings suggest that the Polish population has stronger local identity than the suburbanising Lithuanian population and that Poles are very concerned about their representation in the regional government.

We interpreted our results as follows. The dropping share of votes for the EAPL in the suburbanisation ring is most likely the result of the voter migration effect: Lithuanians from the city move to the suburban ring and vote on different parties than the original population in the region. At the same time we see an increase in the absolute number of votes for the EAPL in the suburban ring and increased voter activity. From this we can derive that the Polish identity residents of the region show increased voter activity in an attempt to protect their weakening position in local politics. Although the Polish party still receives more than $50 \%$ of the votes in the majority of the voting districts, the continuing process of suburbanization poses a threat to the EAPL to lose its dominant positions in the future.

We expect that those places which show increased voter activity, but dropping shares of votes for the EAPL are places of potential tensions between ethnic groups. Those are the places where the differences in needs, priorities, worldviews, etc. are the greatest among two very different ethnic communities. Media announcements have shown that the educational system is now among the main disputes in the region. According to national policy, small schools, mainly Polish identity schools, need to be closed. These closures are regarded as discrimination by the Polish minority, and since Poles still have a majority in most local councils in the region, they keep Polish schools open. Therefore, the network of educational institutions (in terms of language of instruction) does not change with the increasing number of Lithuanians pupils and decreasing number of Polish pupils.

Notwithstanding the fact that electoral data is not perfect, and does not represent all aspects of political preferences of all residents, it is obvious, that the electoral method helps to indicate the "hottest" areas in the region. Using electoral data has also shown to be a useful tool to investigate the spatial patterns of suburbanisation as well as the processes of the formation of ethnic and regional identities. 


\section{Acknowledgements}

We would like to thank the Lithuanian Education Exchanges Support Foundation (grant No. LLP-LdV-PLM-2012-LT-0742) for financial support on a Leonardo da Vinci programme initiated by European Union. We would also like to thank the host institution, OTB Research Institute for the Built Environment at Delft University of Technology in the Netherlands, for its hospitality and for the facilities and office space supplied.

\section{REFERENCES}

Bardauskiene, D and Pakalnis, M (2011) Urbanistinių tendencijų poveikis miesto centro renovacijai [The impact of urban trends on renovation of the city centre]. Urbanistika ir architektūra 35 (4), 276-284.

Bertaud, A and Renaud, B (1997) Socialist cities without land markets. Journal of Urban Economics 41 (1), 137-151.

Bonvalet, C, Carpenter, J and White, P (1995) The residential mobility of ethnic minorities: A longitudinal analysis. Urban Studies 32 (1), 87-103.

Boren, T and Gentile, M (2007) Metropolitan processes in post-communist states: An introduction. Geografiska Annaler 89 (2), 95-110.

Brade, I, Herfer, G and Wiest, K (2009) Recent trends and future prospects of socio-spatial differentiation in urban regions of Central and Eastern Europe: A lull before the storm? Cities 26 (5), 233-244.

Bullock, C S and Hood, M V (2006) A mile-wide gap: The Evolution of Hispanic Political Emergence in the Deep South. Social Science Quarterly 87 (5), 1117-1135.

Burneika, D and Ubarevičienè, R (2011) The sprawl of Vilnius city - some consequences of rural - urban transformations. Annales Geographicae 43-44, 108-115.

Castells, M (2004) The power of identity, Blackwell, Oxford.

Central Electoral Commission. (2012) 1993-2011 electoral data, accessed on 20 October 2012 at www.vrk.lt.

Central Electoral Commission. (2003) http://www3.1rs.lt/rinkimai/2003/referendumas/ rezultatai/rez_e_16.htm, accessed on 10 October 2012.

Chandra, K and Wilkinson, S (2008) Measuring the Effect of 'Ethnicity'. Comparative Political Studies 41 (4-5), 515-563.

Chernyha, L T and Burg, S L (2012) Accounting for the Effects of Identity on Political Behavior: Descent, Strength of Attachment, and Preferences in the Regions of Spain. Comparative Political Studies 45 (6), 774-803.

Clark, W (2006) Race, class, and space: Outcomes of suburban access for Asians and Hispanics. Urban geography 27 (6), 489-506.

Commercio, M E (2004) Exit in the near abroad: the Russian minorities in Latvia and Kyrgyzstan. The Problems of Post-Communism 51 (6), 23-32.

Crowley, J (2001) The Political Participation of Ethnic Minorities. International Political Science Review 22 (1), 99-121.

Daukšas, D (2008) Pase įrašytoji tapatybè: Lietuvos lenkų etninio/nacionalinio tapatumo trajektorijos [Identity Inscribed in the Passport: the Trajectories of Ethnic/national Identity of Lithuanian Poles]. Lietuvos etnologija 17, 57-72.

Enyedi, G (1996) Urbanization under socialism. In Andrusz, G, Harloe, M and Szelenyi, I (Eds.), Cities after Socialism: Urban and Regional Change and Conflict in Postsocialist Societies. Blackwell Publishers, Oxford, pp. 100-118. 
Fennema, M and Tillie, J (2001) Civic Community, Political Participation and Political Trust of Ethnic Groups. Connections 24 (1), 26-41.

Gaučas, P (1997) Etnolingvistinė Rytų Lietuvos gyventojų raida XVII a. antrojoje pusejje 1939 m.: istorinè geografinè analizė [Ethnolinguistic evolution of the development of population in Eastern Lithuania in the second part of the $17^{\text {th }}$ century - 1939: historical geographical analysis]. (doctoral dissertation). Vilnius.

Gentile, M, Tammaru, T and van Kempen, R (2012) Heteropolitanization: Social and spatial change in Central and East European Cities. Cities 29 (5), 291-350.

George, J, Moser, R G and Papic, M (2010) The Impact of Minority-Majority Districts: Evidence from Ukraine. Post-Soviet Affairs 26 (1), 58-76.

Halla, M, Wagner, A F and Zweimüller, J (2012) Does Immigration into Their Neighborhoods Incline Voters Toward the Extreme Right? The Case of the Freedom Party of Austria. www.iza.org

Hamilton, F E I, Andrews, K D and Pichler-Milanovic, N (2005) Transformation of Cities in Central and Eastern Europe - Towards Globalization. United Nations University Press, Tokyo.

Harrison, J (2010) Networks of connectivity, territorial fragmentation, uneven development: The new politics of city-regionalism. Political Geography 29 (1), 17-27.

Hiebert, D (2000) Immigration and the changing Canadian city. The Canadian Geographer 44 (1), 25-43.

Hogan-Brun, G and Ramonienè, M (2003) Emerging language and education policies in Lithuania. Language Policy 2 (1), 27-45.

Jonas, A E G and Ward, K (2007) Introduction to a Debate on City-Regions: New Geographies of Governance, Democracy and Social Reproduction. International Journal of Urban and regional Research 31 (1), 169-178.

Kok, H and Kovács, Z (1999) The Process of Suburbanization in the Agglomeration of Budapest. Netherlands Journal of Housing and Built Environment 14 (2), 119-141.

Kostinskiy, G (2001) Post-Socialist Cities in Flux. In Paddison R (Eds), Handbook of Urban Studies. Sage Publication, London, pp. 451-465

Krišjāne, Z and Bērziņš, M (2009) Commuting and the Deconcentration of the Post-Socialist Urban Population: The Case of the Rīga Agglomeration. Folia Geographica 14, 56-74.

Leetmaa, K and Tammaru, T (2007) Suburbanization in Countries in Transition: Destinations of suburbanisers in the Tallinn metropolitan area. Geografiska Annaler Series B Human Geography 89 (2), 127-146.

Medrano, J D (1994) The Effects of Ethnic Segregation and Ethnic Competition on Political Mobilization in the Basque Country, 1988. American Sociological Review 59 (6), 873889.

Mendelsohn, E (1983) The Jews of East Central Europe between the world wars. Indiana University Press, Bloomington.

Novak, J and Sýkora, L (2007) A City in Motion: Time-Space Activity and Mobility Patterns of Suburban Inhabitants and the Structuration of the Spatial Organization of the Prague Metropolitan Area. Geografiska Annaler Series B Human Geography 89 (2), 147-167.

Nuissl, H and Rink D (2005) The 'product' of urban sprawl in eastern Germany as a phenomenon of post-socialist transformation. Cities 22 (2), 123-134.

Ouředníček, M (2007) Differential Suburban Development in the Prague urban Region. Geografiska Annaler Series B Human Geography 89 (2), 111-126.

Paltanavičiūtè, G (2004) Etninių ir religinių įtampų teritorinè struktūra Lietuvoje [Territorial structure of ethnic and religious tensions in Lithuania]. (doctoral dissertation). Vilnius. 
Petrulis, V (2009) Lietuvos politinio lauko teritorinè struktūra (elektorinio metodo pagrindu) [A territorial structure of Lithuania's political field (On the basis of electoral method]. (doctoral dissertation). Vilnius.

Pileckas, M (2003) Rytų Lietuvos gyventojų nacionalinès sudèties kaita atkūrus Lietuvos valstybingumą [Changes in the national structure of East Lithuanian population after the restoration of Lithuania's independence]. Geografija 39 (1), 40-45.

Robinson, T and Noriega, S (2010) Voter migration as a source of electoral change in the Rocky Mountain West. Political Geography 29 (1), 28-39.

Savukynas, V (2000) Lietuvos lenkai ir rusai: dvi skirtingos laikysenos [Lithuania's Poles and Russians: Two different perspectives]. Politologija 18 (2), 67-84.

Simpson, L and Finney, N (2009) Spatial Patterns of Internal Migration: Evidence for Ethnic Groups in Britain. Population, Space And Place 15 (1), 37-56.

Snyder, T (1995) National Myths and International Relations: Poland and Lithuania,19891994. East European Politics \& Societies 9 (2), 317-343.

Stanaitis, A (2003) Tautiniai pokyčiai Vilniaus mieste XX a. II pusejje [Changes in the national structure of the Vilnius city in the second half of the 20th century]. Geografija 39 (1), 33-39.

Stanaitis, S and Česnavičius, D (2010) Dynamics of national composition of Vilnius population in the $2^{\text {nd }}$ half of the $20^{\text {th }}$ century. Bulletin of Geography. Socio-economic series 13, 31-44.

Stanilov, K (2007) Urban development policies in Central and Eastern Europe during the transition period and their impact on urban form. In Stanilov, K (Eds), The PostSocialist City. Springer, Dordrecht, pp. 347-359.

Statistics Lithuania. (2002) 2001 Census data special request tables.

Statistics Lithuania. (2011) www.statgov.lt, accessed on 12 October 2012.

Statistics Lithuania. (2012) Lithuanian 2011 Population Census in Brief, Vilnius: Statistics Lithuania.

Stravinskienè, V (2004) Lenkai Lietuvoje. 1944 m. antroji pusè - 1946 metai: tarp pasirinkimo likti ar išvykti ị Lenkiją?' [Poles in Lithuania from the second half of 1944 until 1946: choosing between staying or emigrating to Poland], Lietuvos istorijos metraštis 2, 94-115.

Sýkora, L and Ćermák, Z (1998) City growth and migration patterns in the context of 'communist' and 'transitory' periods in Prague's urban development. Espace, populations and societies 3, 405-416.

Sýkora, L and Ouředníček, M (2007) Sprawling post-communist metropolis: Commercial and residential suburbanization in Prague and Brno, the Czech Republic. In Razin E et al. (Eds), Employment Deconcentration in European Metropolitan Areas. Springer, the Netherlands, pp. 209-233.

Tammaru, T and Kulu H (2003) The Ethnic Minorities of Estonia: Changing Size, Location, and Composition. Eurasian Geography and Economics 44 (2), 105-120.

Tammaru, T, Leetmaa, K, Silm, S and Ahas, R (2009) Temporal and Spatial Dynamics of the New Residential Areas around Tallinn. European Planning Studies 17 (3), 423-439.

Tammaru, T, van Ham, M, Leetmaa, K and Kahrik, A (2011) Ethnic Dimension of Suburbanization in Estonia. www.iza.org

Timar, J and Varadi, M M (2001) The Uneven Development of Suburbanization during Transition in Hungary. European Urban and Regional Studies 8 (4), 349-360.

Togeby, L (1999) Migrants at the polls: An analysis of immigrant and refugee participation in Danish local elections. Journal of Ethnic and Migration Studies 25 (4), 665-684. 
Ubarevičienè R, Burneika, D and Kriaučiūnas, E (2011) The sprawl of Vilnius city establishment and analysis of growing urban region. Annales Geographicae 43-44, 96107.

Vaitiekūnas, S (2006) Lietuvos gyventojai per du tūkstantmečius [The population of Lithuania over two Millenium]. Mokslo ir enciklopediju leidybos institutas, Vilnus.

Valionis, A, Ignatavičius, E and Bričkovskienè I (1998) From Solidarity to Partnership: Lithuanian - Polish Relations 1988-1998. Lithuanian Foreign Policy Review 2, 7-29.

van Heelsum A (2005) Political Participation and Civic Community of Ethnic Minorities in Four Cities in the Netherlands. Politics 25 (1), 19-30.

Walks, A (2006) The Causes of City-Suburban Political Polarization? A Canadian Case Study. Annals of the Association of American Geographers 96 (2), 390-414.

Wolfinger, E (1965) The Development and Persistence of Ethnic Voting. The American Political Science Review 59 (4), 896-908.

Zubek, V (1993) New Poland's old dilemma: The Polish minority of Lithuania. Ethnic and Racial Studies 16 (4), 657-682. 